\title{
EMERGENT GENDER RELATIONS IN FEMALE EMPLOYMENT WITHIN THE SOCIAL STRATIFICATION IN RURAL INDIA
}

\author{
Sanghamitra KANJILAL-BHADURI ${ }^{1}$ \\ ${ }^{1}$ Ph.D. Scholar, Department of Economics, University of Calcutta, India \\ Tel.: +91351915579300, Email: bhaduri.sanghamitra@gmail.com
}

\begin{abstract}
The paper has presented an empirical picture of inequalities, both within and outside the labour market for women, from gender relations emerging within the framework of overlapping social stratification in rural India. Analysis is based on secondary data, where the emphasis is not only on measurement of quantitative variables, but also on the interactions between various qualitative, socio-economic and socio-cultural variables. The main finding of the present study is that the participation of women in labour force varies across economic classes, social groups, religions, regions and the rural urban divide. Factors determining labour supply decisions of women are different from those of men. Interconnectedness of female employment with other social parameters, which are outside the realm of the standard labour market analysis, gets highlighted in the study.
\end{abstract}

Keywords: gender relation; female labour force/work force participation; social hierarchy.

JEL Classification: $\mathrm{J}_{16}, \mathrm{~J}_{21}$

\section{Introduction}

The notion of 'work' and 'employment' for women is complex. While economic factors predominantly determine a man's participation in employment, the reasons why women work, or do not work or whether they work part-time or full-time can be diverse and are often rooted in a complex interplay of economic, social, cultural and personal factors.

In India, as in other parts of the world, fewer women participate in employment as compared to men both in urban and rural areas. But more women work as compared to men. This is the backdrop against which this paper analyses 


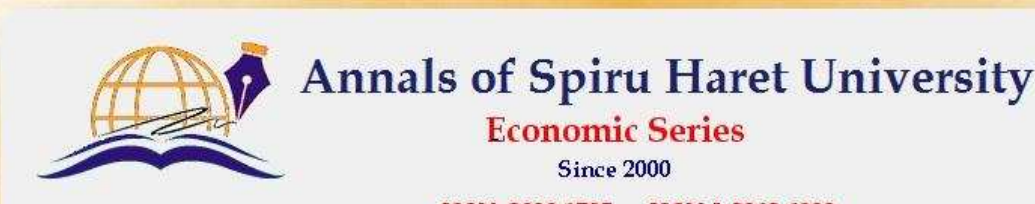

ISSN: 2393-1795 ISSN-L:2068-6900

Issue 2/2017

what gender relations emerge in employment under overlapping class, caste and community identity (religious groups) and finally how such gendering of work has many significant and related consequences.

Rural women have less access than men to productive resources, services and opportunities, such as land, livestock, financial services and education. Numerous studies underscore the social costs of rural women's lack of education and assets, linking it directly to high economic costs: wasted human capital and low labour productivity that stifle rural development and progress. To understand women's work status in India's rural areas and to examine the nature of women's employment, data from large scale National Employment-Unemployment Surveys is analysed in the present study.

Theoretically, female labour supply is often modelled using the framework of the time allocation model (Becker, 1965), which states that women make their labour supply decisions not only considering leisure and labour trade-offs, but also home-based production of goods and services (including caring for children) ${ }^{1}$. Seminal work done by Goldin (1995) explored the U-shaped relationship between female labour supply and the level of economic development across countries. Initially, when the income level is low and the agricultural sector dominates the economy, women's participation in the labour force is high, due to the necessity of working to provide for consumption of goods and services. As incomes rise, women's labour force participation falls, only to rise again when female education levels improve and, consequently, the value of women's time in the labour market increases. This process suggests that, at low levels of development, the income effect of providing additional labour dominates a small substitution effect, while as incomes increase; the substitution effect starts dominating ${ }^{2}$.

The key contribution of this paper is that it explores the dimensions of women's participation; both within the labour market and outside, across socioreligious and socio-economic groups. The interface of class, caste and religion (community identity) with labour market outcomes of women has been explored and it is seen how specific attention to social and cultural variables has relevance for discussions on women's employment (Neetha, 2013). The importance of

\footnotetext{
${ }^{1}$ Hence the need to consider participation of women workers in activities which are outside the production boundary and officially considered as being 'out of labour force'

2 The income effect is the change of hours of work of an individual with respect to a change in family income. The own-substitution effect is the change in hours of work of an individual with respect to change in their wage, holding income constant.
} 


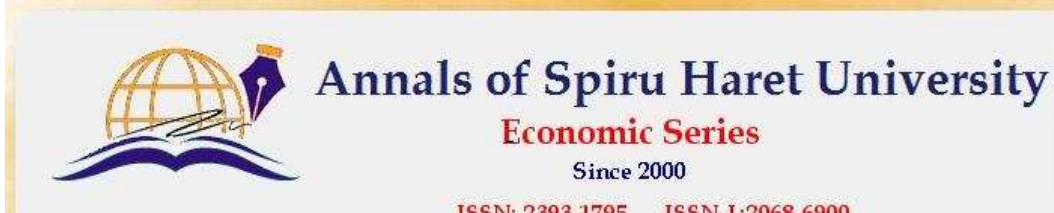

ISSN: 2393-1795 ISSN-I.2068-6900

Issue 2/2017

explicitly drawing distinctions between class, religious and caste categories in the analysis of female employment pattern is highlighted in the paper. The novelty of this study is that it uses a detailed and very large Indian household survey dataset conducted by the National Sample Survey Office (NSSO). Stylised facts from the data are presented in a later section.

\subsection{A History of Gender Relationships}

There are two levels at which women and men interact with each other: there are large-scale, more impersonal gender relations and intimate gendered relationships (Holmes, 2008). At the large-scale level women as a social group are compared to men as a social group. Concerns at that level are with general patterns in how the two groups are positioned in relation to each other within society. The usual framework employed to understand gender relations is the common sociological framework of social stratification and the associated inequalities.

'Social Stratification' refers to the different layers within a society, the hierarchies organised around different groups. The major forms of stratification occur around class, caste, ethnicity or religion and gender. Women's social position has historically been and continues to be one of disadvantage. A lot of research has been done on gender inequalities which mention that women typically have worse jobs, get less pay and are likely to be poorer. Continuity of women's relative disadvantage has been the focus of much research particularly through the 1980s and 1990s. There has also been a growing emphasis on complexity and diversity. Much of empirical research demonstrates that major continuities of inequality still confront women in the labour market (Arber \& Ginn 1995; Hakim 1996; Rubery et al 1999). Gender relations which operate at a large-scale level (studied in the paper) impact gendered relations which are at a more personalised and intimate level.

\subsection{Conceptualising Continuities and Changes of Gender Relations in Employment}

Research regarding gender relations in work and family has been evolving over recent decades (Irwin, 2005). Initially continuities in inequalities were focused but this has given way to recent concern with complexity and diversity. Researchers are now trying to understand how change in gendered employment patterns connects to change in social organisation more widely. There has been a shift in the system of gender relations over the twentieth century, resulting in a change of the pattern of inequality between men and women. Hence a need to develop and apply an intersectional approach to gender analysis has been 


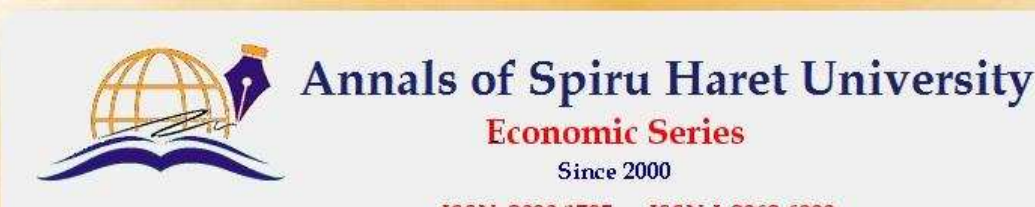

ISSN: 2393-1795 ISSN-L:2068-6900

Issue 2/2017

emphasised by the International Labour Organisation (ILO). Recent research thus focuses more on issues of diversity, complexity and contextual specificities in the reshaping of gender relations within the hierarchies of class, caste, social and religious groups.

\section{Research Objective}

A major gap in the existing literature is the limited attention paid to the representation of class (as proxied by Landownership) and of Caste. Class considerations have been represented in the form of technological change in agricultural methods (Da Corta \& Venkateshwarlu, 1999) or in the form of income classes of the household as represented by monthly per capita expenditure. But the idea that land ownership is a form of wealth which decides the economic class of the household has yet to be exploited in studies. Land holding size from National Sample Survey (NSS) data has been used as one of the many determinants of female labour force participation in studies before but the stratification of social hierarchy in terms of land ownership has been attempted ${ }^{3}$ few and far between. Ownership of land being a historically important indicator of wealth of the households and hence a socio-economic determinant, especially in rural India, warrants a detailed study of its effects on the labour supply decisions of women workers, i.e. on female employment. To try to fill in the existent gaps in the literature this paper has the following objectives:

i. To present a disaggregated analysis of female employment across class, caste and religious identities in rural India

ii. Investigate the causal relationship between socio-economic and socioreligious determinants of female work force participation.

iii. Establish the effectiveness of intersectionality in determining female work force participation.

The social stratification of class has been done by considering 'economic class' which in rural areas is well delineated by the land ownership of the respective households. Greater amounts of land imply higher social positioning and hence a privileged position. Amount of land owned is a strong class stratifier in rural India. Hence the idea of taking up land as one of the causal variable. As female labour is not decided by any single factor but rather by an interplay of various factors so the concept of intersectionality has been utilised. Introduction of

${ }^{3}$ A study by Gita Sen and Chiranjib Sen (1985) has studied the female employment pattern with respect to unpaid work within the land holding sizes of the households. 


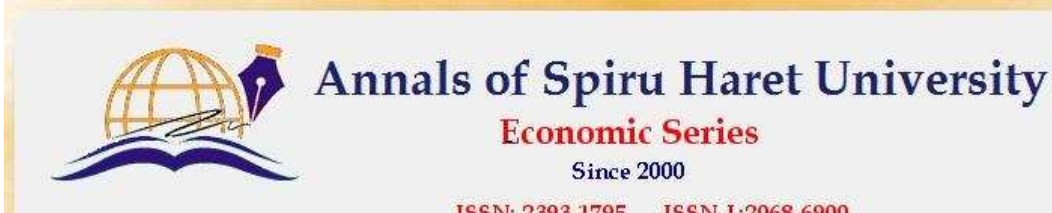

ISSN: 2393-1795 ISSN-I.2068-6900

Issue 2/2017

the interaction terms brings in the concept of 'Intersectionality' (Crenshaw,1989). It enables the present study to consider three dimensional axes at one point of time.

The axes of observation are;

1) landownership class;

2) socio-religious group (interaction terms of social groups and religions); and

3) interaction terms (of land ownership and socio-religious groups).

The extent of female participation in the labour market is determined in India by a nexus of class/caste hierarchy and norms of patriarchal ideology. In a hierarchical society based on patrilineal-patrilocal families, the location of the family in the caste/class hierarchy would determine the level and forms of female work participation (Bardhan, 1985). This observation encouraged a look into the behaviour of female work-participation of the different socio-religious groups in India. These groups have been constructed from NSS data, which gives the position of the household in the socio-religious ladder. Interaction of these socio-religious groups and land ownership has given the position of the household in the class or socio-economic ladder. Econometric estimation and analysis of the impact of these interaction terms on the work participation of female workers has enabled the study to make certain conclusions about the behaviour of female labour supply. It has provided an insight into the employment aspects of women workers belonging to various land ownership classes of the different socio-religious groups. The need for such a study was felt as there are differences in inheritance and asset ownership legislations among the various social and religious groups in India.

\section{Data and Methods}

The data used for analysis in this paper were collected as part of the all India quinquennial survey on Employment-Unemployment by National Sample Survey Office (NSSO). The NSSO carries out all India household survey programme about Employment and Unemployment every 5 years called the quinquennial rounds of Employment and Unemployment Survey (EUS). A nationwide enquiry is conducted to generate estimates of various characteristics pertaining to employment and unemployment and Labour Force characteristics at the National and State levels. Information on various facets of employment and unemployment are collected through a schedule of enquiry (Schedule 10) adopting established concepts, definitions and procedures. Based on the data collected during the entire period of survey, estimates pertaining to employment-unemployment in India along with various characteristics associated with them are presented in the reports. 


\section{Issue 2/2017}

NSSO employs three different methods of determining the activity status of the persons. The first method identifies the Usual Principal Activity Status (called 'Usual Principal Status', UPS) of a person by using a reference period of 365 days preceding the date of survey. A person is considered as being in the Work Force ${ }^{4}$ if he/she is gainfully employed for a major part of the preceding 365 days. The second method considers a reference period of one week (current weekly status) and the third method considers each day of the week (current daily status) 5 . Our study is based on Usual Principal Status (UPS). In the usual status approach, the broad activity status of a person viz. employed, unemployed and 'not in labour force' is decided by major time criterion.

Using employment data from the quinquennial rounds of the National Sample Survey (NSS), several papers/reports have examined the employment situation in India (Dev 2002, Ghose 2004, Masood and Ahmad 2009, Srivastava and Srivastava 2010, Majumder 2011, Mehrotra et al 2012, Shaw 2013). A major conclusion from

4 (i) WORK FORCE PARTICIPATION RATE (WFPR) or WORKER POPULATION RATIO (WPR) is defined as the number of persons/person-days employed per thousand persons/person-days.

Work Force Participation Rate $=$ $=($ Number of persons employed $) /($ total population $) \times 1000$

(ii) LABOUR FORCE PARTICIPATION RATE (LFPR) is defined as the number of person/person days in the labour force per 1000 persons/person days.

\section{Labour Force Participation Rate $=$ (no. of employed persons + no. of unemployed persons)/(total population) $\times 1000$}

It is the economically active population which supplies labour for production and hence includes both 'employed' and 'unemployed' persons.

${ }^{5}$ The NSSO has, over time, developed and standardised measures of employment and unemployment. Four different estimates of the Labour Force and Work Force are obtained based on the 3 approaches adopted in the survey for classification of the population by activity status viz: Usual Status, Current Weekly Status and Current Daily Status. These Are:

(i) Number of persons in the labour/work force according to the 'Usual Status' (ps) i.e by considering usual principal activity only.

(ii) Number of persons in the labour/work force according to the 'Usual Status' (ps+ss) i.e. by considering usual principal and subsidiary activity together.

(iii) Number of persons in the labour/work force according to the 'Current Weekly Status' approach \&

(iv) Number of persons in the labour/work force according to the 'Current Daily Status' approach 


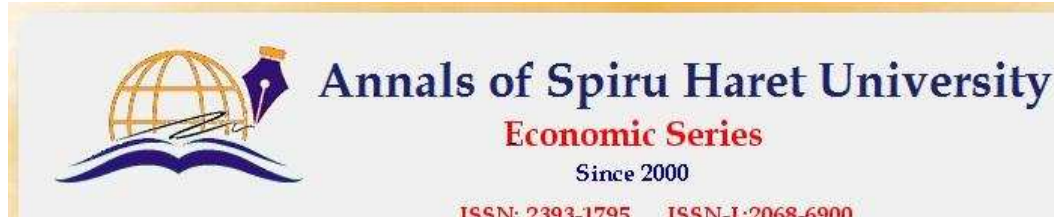

ISSN: 2393-1795 ISSN-I.2068-6900

Issue 2/2017

these studies is the fact that there has been a marked slowdown in employment growth in the year 2011-12 and that this slowdown is more marked for female employment, both in urban as well as rural areas. These studies provide an insight into a neglected area - the female labour supply process in India (Dasgupta and Goldar, 2005).

While mainly economic factors determine a man's participation in employment, the forces that influence a woman's participation are many and diverse and include demographic, reproductive, social, religious and cultural factors. Hence, the decision to participate in the labour force is influenced by women's individual preferences and/or those of her household, family circumstances. The probability of participating in the labour force is thus modelled as a function of several explanatory variables split into categories: individual characteristics, household characteristics, social characteristics and regional characteristics. The existing literature (e.g. Klasen and Pieters 2012, World Bank 2012) suggest that important determinants of participation in India can be education (human capital endowment), family income, socio-economic and cultural factors, access to resources (skills and capital), labour market regulations, and infrastructure. The paper has thus tried to estimate the proximate determinants of the probability of labour force participation for women in rural areas, in the sub-section 3.1. The impact of the significant variables is explored. Stratification is done based on class and hence sub group regressions have been performed for the land ownership classes separately, in section 4 . An effort has been made to highlight the multi dimensionality of determinants of the different economic classes in section 5. Section 6 concludes.

The varying importance of the determinants throws light on the interconnected nature of female employment. It is clearly established that only economic variables are not the deciding factors for female labour force participation. A host of other factors work in unison, as is seen in figure no. 1 below.

The main data set used in the study is Unit Level Data from the NSSO $68^{\text {th }}$ Round for the year 2011-12, extracted from Schedule 10. Logistic regressions have been performed as the dependent variable takes up a binary value. Independent variables are either categorical or continuous. All the statistical work has been done using the software Stata, version 12. Central Sample has been used throughout the study. Data arrangement being very specific to the sections which deal with the various aspects of the analysis of female employment issues have been explained in detail in the respective sections. 
Issue 2/2017

\section{Determinants of female labour force participation}

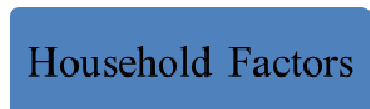

LandOwnership

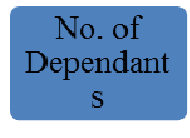

\section{E}
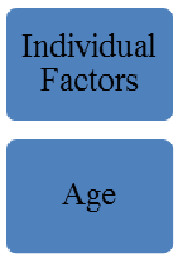

Education

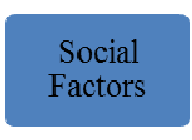

Affiliation to Socioreligious groups
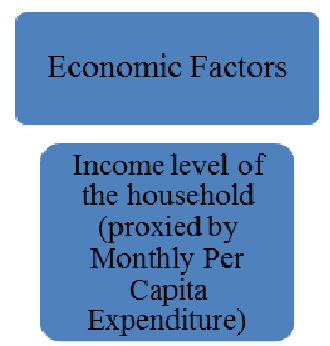

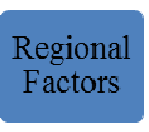

Factors

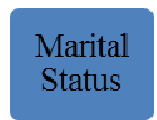 \\ Figure no. 1. Flowchart showing the determinants of female labour force participation for the year 2011-12 (68th Round) at a glance}

Descriptive statistics for the variables used in the analysis in this section are presented in Table A1 and the definition of variables is provided in Table A2.

It is important to note that the data on women's labour force participation in developing countries have been highly criticized as resulting in serious omission of women's work due to undercounting (Jain and Banerjee 1985, Hirway 2002). Much of this criticism has come from Indian feminists who have worked extensively with the National Sample Survey Office to develop more nuanced measures of women's work including questions on non-remunerative activities that are often encompassed under domestic chores such as farm work and looking after livestock (Das and Desai, 2003).

\subsection{Observations}

Regression results from Table no. 1 show that older women in the age group of 30 to 59 years have greater probability of participating in the labour force (with women in the age group 30 to 44 being more probable than the ones in the age group 45 to 59) than women in the age group of 15 to 29 years. This is because after 30 s women generally have reduced reproductive responsibilities. In many 


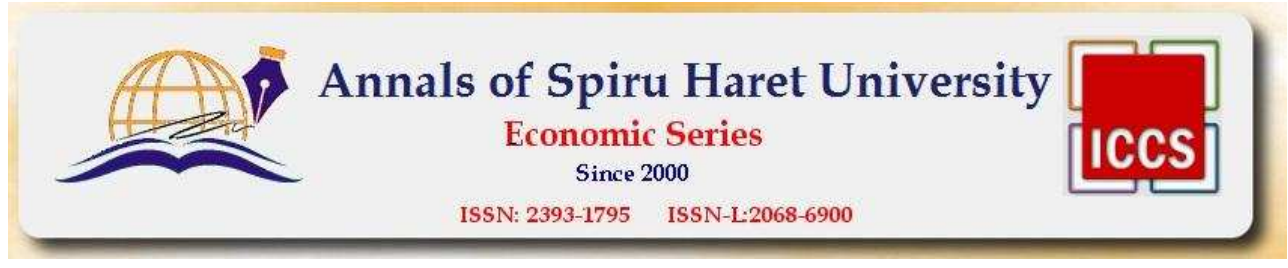

Issue $2 / 2017$

households, the elder kids take care of the younger ones when the mother goes out to work. Care work is always the responsibility of the female hence it is seen that if the household has children less than five years' age or elders above the age of 65 years then the probability of labour force participation lowers significantly. For marital status, with 'never married' status being the reference category it is noticed that there is a significantly higher probability of female workers participating in the labour force. Odds ratios are the highest for 'divorced separated' category, highlighting the distress push that such women face which forces them in the labour market ${ }^{6}$. Education level of the individual has a significant positive impact on labour force participation. An increase in the education level of the woman causes a higher probability of labour force participation.

Table no. 1. Logit Estimates (Odds-Ratio ${ }^{7}$ ) of the determinants of labour-force participation of women workers, 15-59 years, Usual Principal Status

\begin{tabular}{|l|l|}
\hline \multicolumn{1}{|c|}{ Independent Variables } & \multicolumn{1}{c|}{ Female Workers (15-59 years) } \\
\hline Age (Ref:15-29 years) & $\begin{array}{l}\text { 1=In Labour Force } \\
0=\text { Out of Labour Force }\end{array}$ \\
\hline $\mathbf{3 0 - 4 4}$ & $4.22 * * *(0.05)$ \\
\hline $\mathbf{4 5 - 5 9}$ & $3.81 * * *(0.05)$ \\
\hline Marital Status (Ref: Never Married) & \\
\hline Currently Married & $8.53 * *(0.11)$ \\
\hline Widowed & $10.11 * * *(0.24)$ \\
\hline Divorced Separated & $22.22^{* * *}(1.51)$ \\
\hline Education (Ref: Illiterate) & \\
\hline
\end{tabular}

${ }^{6}$ Similar regressions have been carried out for urban area and the odds-ratio for Divorced and Separated women is positive but not so high. It is $6.40(0.52)^{* * *}$. The results have not been published to economise on space.

7 An odds ratio (OR) is a measure of association between an exposure and an outcome. The OR represents the odds that an outcome will occur given a particular exposure, compared to the odds of the outcome occurring in the absence of that exposure.

$\mathrm{OR}=1$ Exposure does not affect odds of outcome

OR>1 Exposure associated with higher odds of outcome

OR $<1$ Exposure associated with lower odds of outcome 
Issue 2/2017

\begin{tabular}{|l|l|}
\hline Below Primary & $0.48^{* * *(0.00)}$ \\
\hline Primary and Middle & $1.03^{* * *(0.01)}$ \\
\hline Secondary and Higher secondary & $1.10^{* * *(0.01)}$ \\
\hline Graduate \& Above(diploma) & $2.26^{* * *(0.04)}$ \\
\hline Households with Children(age<=5yrs) & $0.99(0.00)$ \\
\hline Households with Elderly(age>=65yrs) & $0.72^{* * *(0.00)}$ \\
\hline Land-Ownership (Ref: Landless) & \\
\hline Marginal Owners & $0.82^{* * *(0.04)}$ \\
\hline Small Owners & $1.00(0.05)$ \\
\hline Large Owners & $1.08(0.05)$ \\
\hline MPCE Quartile (Ref: Lowest Quartile) & \\
\hline Second quartile & $0.94^{* * *(0.01)}$ \\
\hline Third quartile & $0.82^{* * *(0.01)}$ \\
\hline Fourth (highest) quartile & $0.62^{* * *(0.00)}$ \\
\hline Social Group (Ref: ST) & \\
\hline SC & $0.76^{* * *(0.01)}$ \\
\hline OBC & $0.66^{* * *(0.01)}$ \\
\hline Others & $0.57^{* * *(0.00)}$ \\
\hline Religion (Ref: Hindu) & \\
\hline Muslims & $0.90^{* * *(0.01)}$ \\
\hline Other-Religions & $1.02^{* *(0.01)}$ \\
\hline Regions (Ref: East) & \\
\hline West & $1.44^{* * *(0.02)}$ \\
\hline Central & $0.83^{* * *(0.01)}$ \\
\hline North & $1.08^{* * *(0.01)}$ \\
\hline South & $1.59^{* * *(0.02)}$ \\
\hline North East & $0.98^{*}(0.01)$ \\
\hline & \\
\hline
\end{tabular}

Ref. implies reference category; $* * *$ implies significance at $1 \%$, ** implies significance at $5 \%$, * implies significance at $10 \%$ level. The figures given in the parenthesis are the robust standard errors. Source: NSSO 68th Round, 2011-12. 


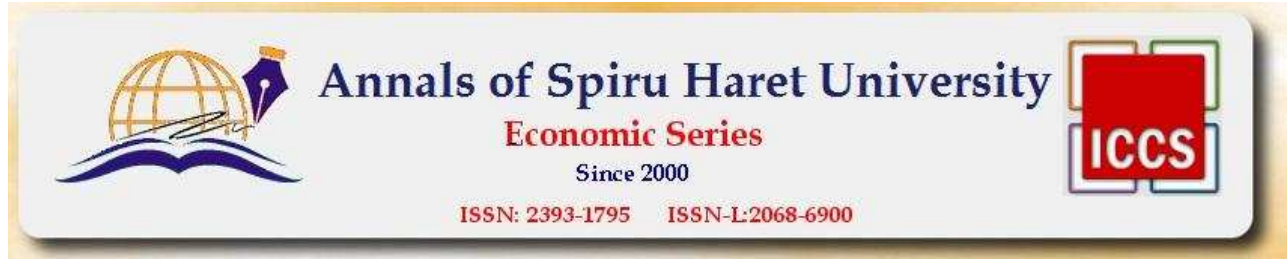

Issue $2 / 2017$

Social groups and religion have a significant effect and results show that there is a lower probability of participation among Scheduled Castes, Other Backward Castes, Others and Muslims. Regions present a varied picture with West, North and South showing a higher probability of participation compared to Central and North-East.

Economic class of the household can either be proxied by the land-ownership or by the monthly per capita expenditure ${ }^{8}$.

a) As the land-ownership of the household increases the probability of labour force participation increases but results are not significant. If the amount of land owned is an indication of wealth of the household then our hypothesis is that with an increasing ownership of land, probability of participation should be less 9 . But results show that there is an increasing probability of participation. This proves that there is some other element which is influencing the labour supply decision of female workers. It will be brought to light in a later section where the participatory process has been explored under the overlap of socio-economic and socio-religious factors influencing female labour supply decision.

b) With an increase in the income of the household the probability of labour force participation of the female worker lowers ${ }^{10}$.

This study seeks to bring forth the gender relations in employment under the social hierarchies. As such a process works under the social stratification of class, caste, gender and religion so in the next section sub group regressions for the different land-ownership classes have been performed to see the determinants which are affecting participation of women in labour force.

\section{Economic Class as a Determinant of Rural Female Employment}

In this section, an effort has been made to elucidate the factors which play an important role in female labour supply decisions in rural India in the $68^{\text {th }}$ round, 2011-12. Such an exercise has been performed within the stratification of the

\footnotetext{
${ }^{8}$ The study considers land ownership only, as it is in the rural backdrop and because of the fact that the stratification according to class has been defined in terms of land ownership. Sub group Regressions have been run for mpce classes in rural and urban areas though, but the results have not been published.

9 It maybe due to the 'stigma effect' as mentioned by Goldin (1995) in the U-Hypothesis.

10 'Income Effect' as mentioned by Neff et al. (2012) and Rangarajan et al. (2014)
} 


\section{Issue 2/2017}

economic class. Separate sub group regressions have been run for each landownership class to verify if the deciding factors are different for each of the class. Table 2 shows that for each land-owning class, a host of varying factors are significant in determining the probability of participation for the women workers. What has also been endeavoured is to check if there is a uni-dimensionality in these factors. The results have established the significant role of multi-dimensionality through the interplay of social, cultural and demographic factors.

Table no. 2. Results (Odds-Ratio) of logistic regression for women workers (15-59 years), 2011-12 according to Usual Principal Status

\begin{tabular}{|c|c|c|c|c|}
\hline \multirow{2}{*}{$\begin{array}{l}\text { Independent } \\
\text { Variables }\end{array}$} & $\begin{array}{l}1=\text { InLabForc } \\
\mathrm{e} \\
0=\text { Not in } \\
\text { LabForce }\end{array}$ & $\begin{array}{l}1=\text { InLabForce } \\
0=\text { Not in } \\
\text { LabForce }\end{array}$ & $\begin{array}{l}1=\text { InLabForce } \\
0=\text { Not in } \\
\text { LabForce }\end{array}$ & $\begin{array}{l}1=\text { InLabForce } \\
0=\text { Not in } \\
\text { LabForce }\end{array}$ \\
\hline & LANDLESS & $\begin{array}{l}\text { MARGINAL } \\
\text { LANDOWNE } \\
\text { RS } \\
\end{array}$ & $\begin{array}{l}\text { SMALL } \\
\text { LANDOWNE } \\
\text { RS }\end{array}$ & $\begin{array}{l}\text { LARGE } \\
\text { LANDOWNE } \\
\text { RS }\end{array}$ \\
\hline \multicolumn{5}{|l|}{ Age (Ref: 15-29) } \\
\hline $30-44$ & $3.23(0.4)^{* * *}$ & $4.76(0.07) * * *$ & $3.46(0.08) * * *$ & $3.94(0.10) * * *$ \\
\hline $45-59$ & $\begin{array}{l}2.80(0.48) * * \\
*\end{array}$ & $4.23(0.07) * * *$ & $3.45(0.09)^{* * *}$ & $3.29(0.09)^{* * *}$ \\
\hline \multicolumn{5}{|l|}{$\begin{array}{l}\text { Marital Status (Ref: } \\
\text { Never Married) }\end{array}$} \\
\hline Currently Married & $\begin{array}{l}6.15(1.02) * * \\
*\end{array}$ & $7.06(0.12) * * *$ & $12.15(0.35)^{* * *}$ & $10.07(0.30)^{* * *}$ \\
\hline Widowed & $\begin{array}{l}8.47(2.58) * * \\
*\end{array}$ & $9.95(0.31) * * *$ & $10.22(0.51)^{* * *}$ & $10.74(0.60)^{* * *}$ \\
\hline Divorced/Separated & $5.43(0.05)^{* *}$ & $18.59(1.64)^{* * *}$ & $18.07(2.99)^{* * *}$ & $42.34(6.22)^{* * *}$ \\
\hline \multicolumn{5}{|l|}{$\begin{array}{l}\text { Education } \quad \text { (Ref: } \\
\text { Illiterate) }\end{array}$} \\
\hline Below Primary & $\begin{array}{l}0.30(0.05)^{* *} \\
*\end{array}$ & $0.499(0.00)^{* * *}$ & $0.51(0.01) * * *$ & $0.44(0.01)^{* * *}$ \\
\hline $\begin{array}{ll}\text { Primary and } \\
\text { Middle }\end{array}$ & $0.92(0.14)$ & $1.08(0.01) * * *$ & $1.08(0.02)^{* * *}$ & $0.89(0.02)^{* * *}$ \\
\hline $\begin{array}{l}\text { Secondary and } \\
\text { Higher secondary }\end{array}$ & $0.83(0.14)$ & $1.156(0.02)^{* * *}$ & $1.27(0.03) * * *$ & $0.90(0.02)^{* * *}$ \\
\hline $\begin{array}{l}\text { Graduate \& above } \\
\text { (diploma) }\end{array}$ & $2.68(0.5)^{* * *}$ & $2.45(0.06)^{* * *}$ & $2.15(0.09)^{* * *}$ & $2.06(0.08) * * *$ \\
\hline
\end{tabular}


Issue 2/2017

\begin{tabular}{|c|c|c|c|c|}
\hline $\begin{array}{l}\text { Households with } \\
\text { children }(<=5 \text { years })\end{array}$ & $0.98(0.06)$ & $0.98(0.00)^{* * *}$ & $1.00(0.01)$ & $0.99(0.01)$ \\
\hline $\begin{array}{l}\text { Households with } \\
\text { elderly }(>=65 \text { years })\end{array}$ & $\begin{array}{l}0.61(0.07)^{* *} \\
*\end{array}$ & $0.69(0.00)^{* * *}$ & $0.79(0.01)^{* * *}$ & $0.71(0.01)^{* * *}$ \\
\hline \multicolumn{5}{|c|}{\begin{tabular}{l|l} 
MPCE Quartile (Ref: & \\
Lowest quartile) & \\
\end{tabular}} \\
\hline Second Quartile & $1.17(0.21)$ & $0.93(0.01)^{* * *}$ & $0.99(0.02)$ & $0.92(0.02) * * *$ \\
\hline Third Quartile & $0.99(0.18)$ & $0.80(0.01)^{* * *}$ & $0.83(0.02)^{* * *}$ & $0.84(0.02)^{* * * *}$ \\
\hline $\begin{array}{l}\text { Fourth } \\
\text { Quartile }\end{array}$ & $\begin{array}{l}0.71(0.14)^{* *} \\
*\end{array}$ & $0.58(0.01)^{* * *}$ & $0.64(0.01)^{* * *}$ & $0.71(0.02) * * *$ \\
\hline \multicolumn{5}{|l|}{$\begin{array}{l}\text { Social } \quad \text { Group } \\
(\text { Ref:ST) }\end{array}$} \\
\hline SC & $1.05(0.24)$ & $0.79(0.01)^{* * *}$ & $0.65(0.02) * * *$ & $0.76(0.03)^{* * * *}$ \\
\hline OBC & $0.80(0.17)$ & $0.67(0.01)^{* * *}$ & $0.59(0.01)^{* * *}$ & $0.70(0.02)^{* * *}$ \\
\hline Others & $0.68(0.13)^{*}$ & $0.57(0.01)^{* * *}$ & $0.51(0.01)^{* * *}$ & $0.60(0.02)^{* * *}$ \\
\hline \multicolumn{5}{|l|}{\begin{tabular}{ll|} 
Religion $\quad$ (Ref: \\
Hindu)
\end{tabular}} \\
\hline Muslims & $0.81(0.11)$ & $0.94(0.01)^{* * *}$ & $0.72(0.02) * * *$ & $1.00(0.03)$ \\
\hline Other Religions & $1.46(0.27)^{* *}$ & $1.09(0.02)^{* * *}$ & $1.02(0.03)$ & $0.88(0.03)^{* * *}$ \\
\hline \multicolumn{5}{|l|}{ Regions (Ref: East) } \\
\hline West & $0.97(0.20)$ & $1.30(0.03) * * *$ & $1.65(0.06)^{* * *}$ & $1.58(0.06)^{* * *}$ \\
\hline Central & $\begin{array}{l}0.48(0.11)^{* *} \\
*\end{array}$ & $0.81(0.01)^{* * *}$ & $0.95(0.03)$ & $0.83(0.03) * * *$ \\
\hline North & $0.77(0.17)$ & $0.97(0.02)$ & $1.51(0.05)^{* * *}$ & $1.03(0.04)$ \\
\hline South & $1.19(0.28)$ & $1.44(0.03) * * *$ & $2.17(0.07)^{* * *}$ & $1.57(0.06)^{* * *}$ \\
\hline North East & $0.72(0.15)$ & $0.93(0.02)^{* * *}$ & $1.18(0.04)^{* * *}$ & $1.01(0.04)$ \\
\hline
\end{tabular}

Ref. implies reference category; $* * *$ implies significance at $1 \%$, ** implies significance at $5 \%$, * implies significance at $10 \%$ level. The figures given in the parenthesis are the robust standard errors. Source: NSSO 68th Round, 2011-12.

\subsection{Snapshot of the important determinants}

Below, a summary of the determinants which are significant in female labour force participation for women belonging to the four categorised land-ownership classes has been provided 

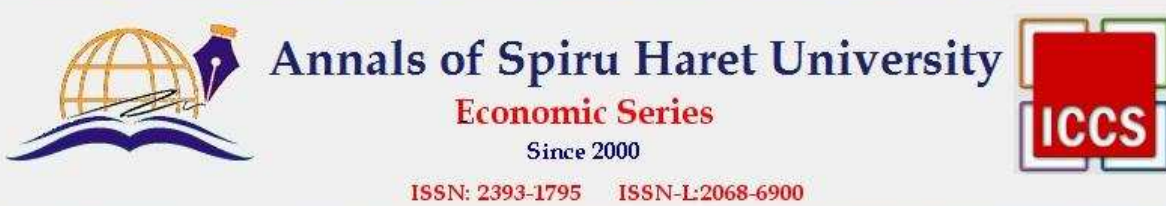

Issue 2/2017

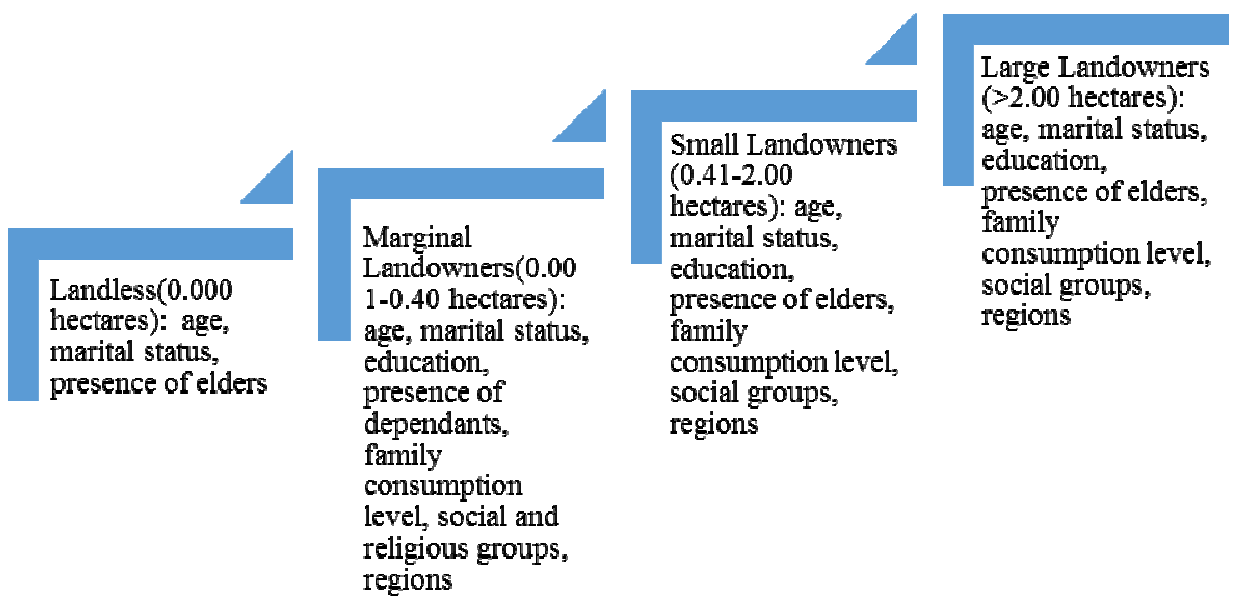

Figure no. 2. Significant determinants of female labour force participation for the different land-ownership classes

From Figure no. 2 it is evident that the interconnectedness of social and economic factors plays a very important role in determining female labour supply. Gender relations being created in the employment process are not in favour of women. While employment issues in India centrally focus around the category of gender, by mentioning quantitative levels of female employment, the issues of patriarchy, domestic subordination, biological determinism, reproductive norms etc. are not taken into consideration ${ }^{11}$. These are often informed by the crosslinkages with identities of class and caste. These categories often overlap with gender. The importance of intersectionality has been established which leads us to our next econometric specification.

\section{Religion}

5. Female Work Force Participation under the Overlap of Class, Caste And

A lot has been studied about the different determinants of female labour supply process in the Indian Economy along a single axis. Studies on female employment need to delve more into the overlap (McBride et al. 2014) of the axes

\footnotetext{
${ }^{11}$ http://vle.du.ac.in/mod/book/print.php?id=13454\&chapterid=29812
} 

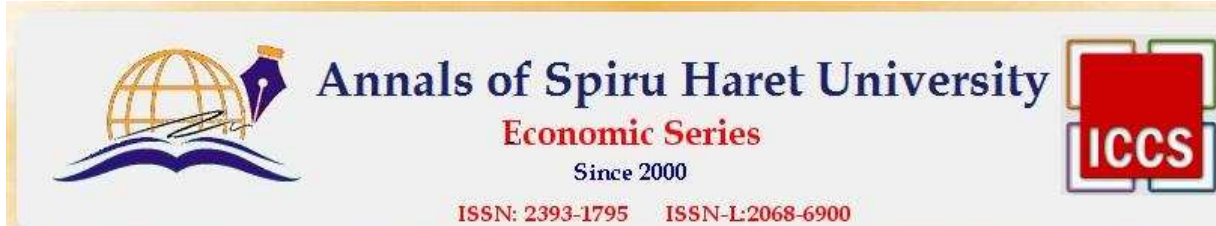

ISSN: $2393-1795$ ISSN-I.2068-6900

Issue $2 / 2017$

of class, caste and religious identities and the cross linkage of the variables in influencing the decision of female labour supply. This section has tried to focus on this aspect. Economic class has been proxied by land-ownership, caste and religious identities have been proxied by creating socio-religious groups from NSS data. Wealth being a stock concept, its availability with the households should affect the decision of the family to send their women folk to work. This would be applicable not only for the current generation but for future as well as the past generations also. So, there would be an intergenerational impact of this determinant of female labour supply. The present section, however, has focussed only at the effect on the present generation of women workers in the $68^{\text {th }}$ Round for the year 2011-12.

\subsection{Model}

Total no. of observations in the 68th Round=4,56,999 individuals.

This includes both males and females in rural as well as urban areas. For this specific study only females have been considered and then the data set reduces to $2,23,195$ persons. An attempt is made to analyse the employment behaviour of female workers, so the data set consists of working age females in the age group 15-59 years. Now the data set consists of 1,42,776 persons. After adjusting for work-force participation of female workers in rural areas the final data-set is 90,230 persons.

For considering Work-Participation of Female Workers (in the age group of 15-59 years) in the Usual Principal Activity Status the data has been arranged in the following manner:

i. Usual Principal Activity Status code $81^{12}$ (as per NSSO schedule) has not been taken into consideration as that will give us the Labour Force estimate but we are considering Work-Force participation only.

ii. Usual Principal Activity Status code $91^{13}$ (attending educational institutions) has been considered 'out of labour force' (as per NSSO directive),

iii. Usual Principal Activity Status codes $\left[\left(92^{14}, 93^{15}\right),\left(94,95,97^{16}\right)\right]$ have not been taken into consideration as they do not enable us to define work-participation

\footnotetext{
${ }^{12}$ Did not work but was seeking and/or available for work - Upa81.

${ }^{13}$ Attended educational institution - Upa91.

${ }^{14}$ Attended domestic duties only - Upa92.
} 


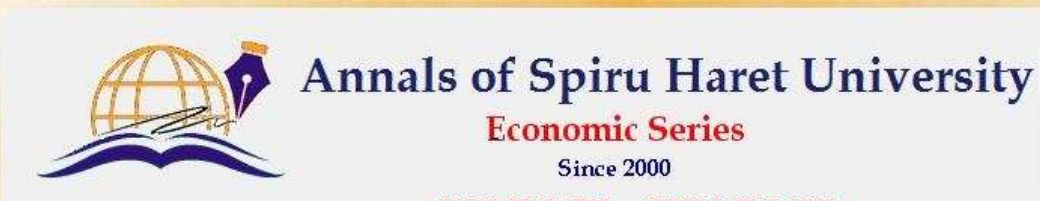

ISSN: 2393-1795 ISSN-L:2068-6900

\section{Issue 2/2017}

as gainful employment. \{ These codes describe activities which are not remunerable or done for gainful purposes

iv. An observation needs to be made here: Although Upa $21^{17}$ defines unpaid family worker yet we have considered it in Work Participation because as landownership increases there is a greater representation of working age women in the family who work as unpaid family labour. Most of the unpaid agricultural (on owned farms) or non-agricultural (in own household enterprise) work is done by female workers of the household. Taking Upa21 into consideration or leaving it out of the definition of Work Participation changes the econometric results for the different socio-religious groups.

$$
\begin{aligned}
& \text { Work-Participation }=\text { Usual Principal Activity Status } \\
& {\left[\left(11^{18}+12^{19}\right)+21\right]+31^{20}+\left[\left(41^{21}+51^{22}\right)\right]}
\end{aligned}
$$

Final size of the dataset $=90230$ (observations). Over this data set describing and testing of the hypotheses is done using the Binary Logit framework.

The Model can be expressed as follows:

$$
\text { Logit } \mathrm{x}=\propto_{0}+\sum_{i=1}^{k} \propto_{i} \boldsymbol{Y}_{i}
$$

Where $\mathrm{x}$ is the probability that an individual participates in workforce;

$$
\text { Logit } \mathrm{x}=\ln \left(\frac{x}{1-x}\right)
$$

$\left\{Y_{i}\right\}(\mathrm{i}=1,2, \ldots, \mathrm{k})$ are the predictor variables, $\propto_{0}$ is the intercept and $\propto_{i} \mathrm{~s}$ are the regression coefficients.

${ }^{15}$ Attended domestic duties and was also engaged in free collection of goods (vegetables, roots, firewood, cattle-feed, etc.), sewing, tailoring, weaving, etc. for household use - Upa93.

${ }^{16}$ Rentiers, Pensioners, Remittance recipients etc. - Upa94, Not able to work due to disability - Upa95, Others (including begging, prostitution, etc.) - Upa97.

${ }^{17}$ Worked as helper in h.h enterprise (unpaid family worker) - Upa21.

${ }^{18}$ Worked in h.h. enterprise (self-employed): own account worker - Upa11.

${ }^{19}$ Employer - Upa12.

${ }^{20}$ Worked as regular salaried/ wage employee - Upa31.

${ }^{21}$ Worked as casual wage labour: in public works - Upa41.

${ }^{22}$ Worked as a casual wage labour in other types of work - Upa51. 
Table no. 3. Odds ratios explaining female participation (68th Round)

\begin{tabular}{|c|c|c|}
\hline & \multicolumn{2}{|l|}{ Model1 } \\
\hline Land-Classes & Wfpr (with UPA21) & Wfpr (without UPA21) \\
\hline Landless $^{1}$ & Ref & Ref \\
\hline Marginal Land Owner & $0.99(0.08)$ & $0.99(0.08)$ \\
\hline Small Land Owner & $1.04(0.08)$ & $0.88(0.07)$ \\
\hline \multirow[t]{2}{*}{ Large Land Owner } & $1.07(0.01)$ & $0.94(0.07)$ \\
\hline & \multicolumn{2}{|l|}{ Model2 } \\
\hline \multicolumn{3}{|l|}{ Socio-religious grps } \\
\hline Hindu-STs $^{2}$ & Ref & Ref \\
\hline Hindu-Others & $0.82(0.02)^{* * *}$ & $0.85(0.02) * * *$ \\
\hline Hindu-SCs & $0.82(0.03)^{* * *}$ & $0.93(0.03)^{* *}$ \\
\hline Muslims & $0.64(0.03)^{* * *}$ & $0.70(0.02)^{* * *}$ \\
\hline Other-Religions & $0.72(0.03) * * *$ & $0.75(0.02) * * *$ \\
\hline \multicolumn{3}{|c|}{ Model3 } \\
\hline \multicolumn{3}{|l|}{ Interaction Terms } \\
\hline \multicolumn{3}{|l|}{ Hindu-Others } \\
\hline Landless & Ref & Ref \\
\hline Marginal & $1.02(0.08)$ & $1.01(0.08)$ \\
\hline Small & $1.08(0.08)$ & $0.93(0.08)$ \\
\hline Large & $1.12(0.08)$ & $0.96(0.08)$ \\
\hline \multicolumn{3}{|l|}{ Hindu-SCs } \\
\hline Landless & Ref & Ref \\
\hline Marginal & $1.07(0.09)$ & $1.11(0.09)$ \\
\hline Small & $1.11(0.09)$ & $1.02(0.09)$ \\
\hline Large & $1.04(0.09)$ & $0.95(0.09)$ \\
\hline \multicolumn{3}{|l|}{ Hindu-STs } \\
\hline Landless & Ref & Ref \\
\hline Marginal & $1.30(0.12)^{* * *}$ & $1.32(0.12) * * *$ \\
\hline
\end{tabular}


Issue $2 / 2017$

\begin{tabular}{|l|l|l|}
\hline Small & $1.2(0.09)$ & $1.01(0.09)$ \\
\hline Large & $1.30(0.10)$ & $1.00(0.10)$ \\
\hline Muslims & Ref & Ref \\
\hline Landless & $0.85(0.07)^{* *}$ & $0.82(0.07)^{* *}$ \\
\hline Marginal & $0.77(0.06)^{* * *}$ & $0.69(0.06)^{* * *}$ \\
\hline Small & $0.95(0.08)$ & $0.89(0.08)$ \\
\hline Large & \multicolumn{2}{|l|}{} \\
\hline Other-Religions & Ref & Ref \\
\hline Landless & $0.93(0.07)$ & $0.90(0.07)$ \\
\hline Marginal & $0.96(0.07)^{* * *}$ & $0.88(0.07)^{* * *}$ \\
\hline Small & $0.93(0.08)$ & $0.87(0.08)^{*}$ \\
\hline Large &
\end{tabular}

Note: $1 \& 2$ are reference categories because they have lowest representation in sample. Ref. implies reference category; $* * *$ implies significance at $1 \%, * *$ implies significance at $5 \%$, * implies significance at $10 \%$ level. The figures given in the parenthesis are the robust standard errors. Source: NSSO 68th Round, 2011-12

\subsection{Observations}

The results of the micro decision making process (Table 3) as evident from the binary choice model are explored. The model uses land (categorised as marginal, small and large), socio-religious groups (categorised as Hindu-Others, Hindu-SC, Hindu-ST, Muslims and Other Religions), interaction terms of land and socio-religious groups and sector (categorised as rural and urban) as the causal variables.

\subsubsection{Model 1}

The most important result from this model is that economic class is not a significant variable in determining whether the women worker will take part in work-force or not. Women workers belonging to marginal landowning households have a lower probability of working. Those from small and large landowning have a greater probability of taking part in work force. There is no inverse relationship between land-ownership classes and female work-force participation implying that the 'income effect' is not at work in the year 2011-12. 

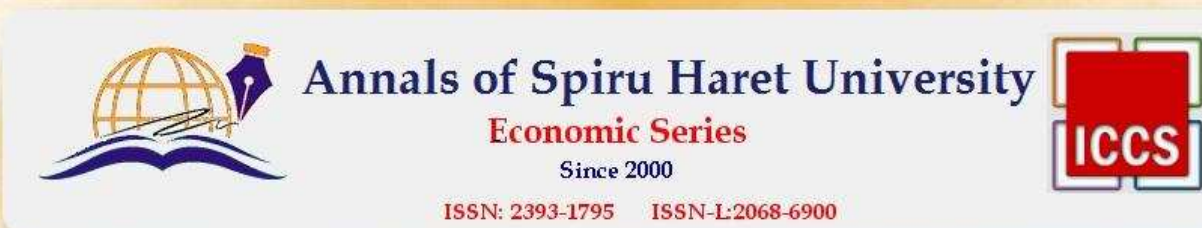

ISSN: $2393-1795$ ISSN-I.2068-6900

Issue $2 / 2017$

This is mainly due to the presence of Unpaid home based work (Upa21) because when binary logit without including this kind of work in the definition of work participation is performed then results show that there is an inverse relation between the two variables. The tables showing both the regression results have been presented.

As the ownership of land increases there is a lower probability of women workers working when the 'unpaid work'(Upa21) done by women workers is not considered, but once this work is taken into consideration the work force participation increases with increase in land ownership size.

This is a representation of the fact that for female workers the decision to participate in work force is not a simple function of economic or social or demographic or cultural factors. There are elements beyond these determinants which must be factored in to get the actual scenario.

The forces at play in determining whether a women worker will provide labour supply are varying. This proves the fact that unlike for male, female labour force participation is an interplay of a myriad factors. The interconnectedness of female labour is clearly brought out from the results.

Asset ownership laws are varied among the different socio-religious groups in India. To study the impact of such differences we have studied female workparticipation behaviour among the various socio-religious groups.

\subsubsection{Model 2}

Hindu-STs (Schedule tribes who are Hindus) are considered as the reference category for the next section of study involving socio-religious groups as they are least represented in the sample.

Women workers from Hindu-Others, Hindu-SCs, Muslims (considering MusSTs, Mus-SCs, Mus-Others and Mus-OBCs) and Other-Religions have a significantly lower probability of taking part in work-force participation, irrespective of the presence or absence of non-remunerative work done on own farm or household enterprise (Upa21) in both the rounds. This proves the importance of caste as a variable in determining the trend of female labour supply.

In the social stratification of class and caste, in the $68^{\text {th }}$ round, class loses its significance and the composition of work done by the women worker gains more importance. 


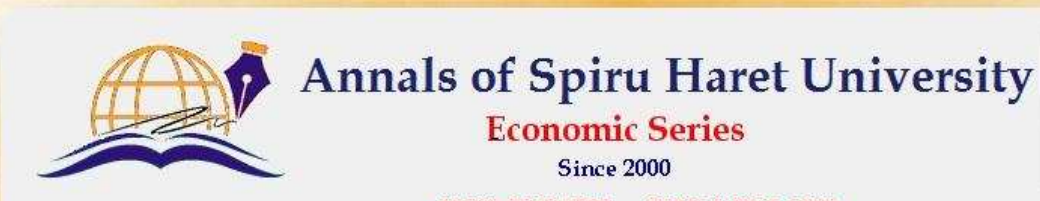

ISSN: 2393-1795 ISSN-L:2068-6900

Issue $2 / 2017$

\subsubsection{Model 3}

The overlap of economic class, caste, religion and gender is studied with the concept of intersectionality by looking at the impact of the interaction of land and socio-religious groups on female work participation. Results show that for HinduOthers, women workers belonging to marginal, small and large landownership households have a greater probability of working. Presence of land as a productive asset, which is a form of wealth, is not affecting work participation favourably, i.e. there is no inverse relationship between landownership and Female Work Force Participation Rate among this socio-religious group. This is again due to the presence of 'unpaid work (Upa21)' in the definition of work participation. As there is no clarity about the ownership rights of the available land with the households, it has been assumed that the women workers have the same right to ownership as their male counterparts.

For Hindu-SCs and Hindu-STs, the results show that women workers from marginal, small and large landowning households have a greater probability of working. This is irrespective of whether unpaid work in household farms is included or not. So, the overlap of class, caste and religion determine the employment relations for women workers. An increase in wealth is not affecting the work participation decision favourably.

For Muslims and Other-Religions too the lower probability of work force participation by women workers, both in case of the presence or absence of unpaid work on household farms again reiterates the fact that the Overlap plays an important role in decision making.

Thus, interconnectedness of economic and social variables play a strong role in determining female work force participation whereas economic variables are stronger in determining male work force participation ${ }^{23}$.

\section{Conclusion}

Main finding of the present study is that the participation of women in labour force varies across economic classes, social groups, religions, regions and the rural urban divide. Labour force participation is the outcome of both the supply-side

${ }^{23}$ As a robustness check similar exercises have been performed for male workers (15-59 years). It has been found that class plays an important role in the decision-making process of male labour supply. Caste and composition of work do not have a significance. Overlap does not bring about any changes in the decision-making process. Results have not been published to economise on space. 


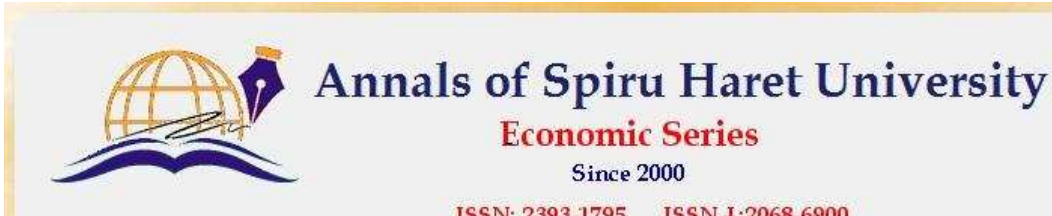

ISSN: 2393-1795 ISSN-I:2068-6900

Issue 2/2017

factors and the demand for labour. Factors determining labour supply decisions of women are different from those of men. Interconnectedness of female employment with other social parameters which are outside the realm of the standard labour market analysis gets highlighted in the study. This is responsible for creating puzzling trends and patterns in employment data. It is also responsible for the gender gap in labour force and workforce levels. Social and religious background is an important determinant of labour market participation for both men and women. Relative influence of social and religious background is much higher for females (Neetha, 2013). The differences in male and female participation rates, controlling for demographic variables and education is partly explained by this peculiarity of female employment. In fact, women belonging to different social, cultural and religious backgrounds exhibit varying participation rates in the activity statuses enumerated by NSS data. This fact has been corroborated in the paper, where econometric analyses have revealed that women belonging to different socio-economic and socio-religious groups have varying participation rates in the workforce. Large anecdotal evidence suggests that female behaviour in labour market is dramatically affected by their and their household's religious beliefs (Pastore and Tenaglia, 2013). Results of this study depict that socio-religious groups are significant determining factors for work force participation. So, the determinants which are significant for female employment are not on a single axis of consideration, they are always intertwined and manifest themselves along multiple axes. Hence, the gender relations emerging in the employment process are not always in favour of women. It is evident that majority of women in rural areas are subjugated to such relations, i.e. they cannot participate in the labour/work force independent of the relations. Women must decide to participate in the labour/work force within the boundaries of the gender relations which are created in the households or the work place.

Multiple layers of the society are referred to as 'Social Stratification'. The paper has presented an empirical picture of labour market inequalities for women and the inequalities outside, within the framework of such overlapping stratification in rural India. Analysis is based on secondary data, where the emphasis is not only on measurement of quantitative variables, but also on the interactions between various qualitative, socio-economic and socio-cultural dimensions which have an implication on female participation in the labour force. Clear and significant results are obtained when the interaction between landownership categories and socio-religious groups are taken into consideration. The multi dimensionality of the data provides a definite 


\section{Issue 2/2017}

pattern of the employment of women workers within the gender relations created thereof.

\section{References}

1. Arber, S. and Jay Ginn. (1995), "Connecting Gender and Ageing: A Sociological Approach", Open University Press.

2. Bardhan, K. (1985), "Women's Work, Welfare and Status: Forces of Tradition and Change in India", Economic and Political Weekly, Vol. 20, No. 50 (Dec. 14, 1985), pp. 2207-2220.

3. Bardhan, Pranab. K. (1979), "Labor Supply Functions in a Poor Agrarian Economy", American Economic Review, Vol.69, No.1, pp 73-83.

4. Becker, Gary. S. (1971), "The Economics of Discrimination", University of Chicago Press (Second Edition), Chicago and London.

5. Becker, Gary. S. (1981), "A Treatise on the Family", Harvard University Press, Cambridge.

6. Beneria, L. (1995), "Toward a greater integration of gender in economics", World Development, Vol. 23, No. 11, November 1995, Pages 1839-1850.

7. Beneria, L. (1999), “The Enduring Debate over Unpaid Labour." International Labour Review, Vol. 138, No. 3, pp 287-309.

8. Beneria, L and Gita Sen. (1981), "Accumulation, Reproduction, and 'Women's Role in Economic Development': Boserup Revisited”, Chicago Journals, Signs, Vol. 7, No. 2, Development and the Sexual Division of Labor (Winter, 1981), pp. 279-298.

9. Chaudhary, R and Sher Verick. (2014), "Female labour force participation in India and beyond", ILO Asia-Pacific Working Paper Series.

10. Crenshaw, Kimberle (1989). "Demarginalizing the Intersection of Race and Sex: A Black Feminist Critique of Antidiscrimination Doctrine, Feminist Theory and Antiracist Politics". University of Chicago Legal Forum, Vol. 140, pp 139-167.

11. Da Corta, L and Davuluri Venkateshwarlu. (1999), "Unfree relations and the feminisation of agricultural labour in Andhra Pradesh, 1970-95", The Journal of Peasant Studies, Vol. 26, 1999, Issue 2-3, "Rural Labour Relations in India".

12. Das, Maitreyee. B. (2006), "Do traditional axes of exclusion affect labour market outcomes in India?", Social Development Papers, South Asia Series, No. 97, Washington DC, World Bank.

13. Das, Maitreyee. B. and Sonalde Desai. (2003), "Why are Educated Women Less Likely to be Employed in India? Testing Competing Hypotheses", Social Protection Discussion Papers Series, No. 0313, Social Protection Unit, Human Development Network, The World Bank.

14. Das, S. et al (2015), "Women workers in India: Why so Few Among so Many?", IMF Working Paper, WP/15/155, March 2015. 


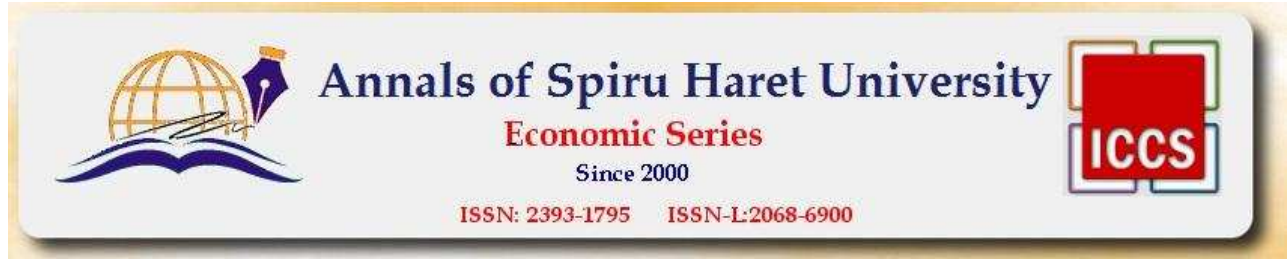

Issue $2 / 2017$

15. Desai, S. and Jain, D. (1994), "Maternal employment and changes in family dynamics: The social context of women's work in rural South India", Population and Development Review, Vol. 20, No. 1, pp. 115-136.

Dev, Mahendra. S. (2000), "Economic Reforms, Poverty, Income Distribution and Employment", Economic and Political Weekly Vol. 35, No.10, (Mar 4-10, 2000), pp 823-835.

16. Gaddis, I. and Stephan Klasen. (2012), "Economic Development, Structural Change and Women's Labor Force Participation: A Re-Examination of the Feminization U Hypothesis". University of Gottingen, Germany, www.unisg.ch/ /media/Internet/Content/Dateien/.../SEW/.../2012/Klasen_Paper.ashx

17. Garikipati, S. (2008), "Agricultural wage work, seasonal migration and the widening gender gap: evidence from a semi-arid region of Andhra Pradesh", The European Journal of Development Research, Vol. 20, 2008, Issue 4: "India's Semi-Arid Rural Economy: Livelihoods, Seasonal Migration and Gender"

18. Ghose, Ajit. K. (2004), "The Employment Challenge in India”, Economic and Political Weekly, Vol. 39, No. 48, (Nov 27-Dec 3, 2004), pp. 5106-5116.

19. Ghosh, J. (2009), "Never Done and Poorly Paid: Women's Work in Globalising India", Signs, Vol. 37, No. 1 (September 2011), pp. 247-251, University of Chicago Press Journals.

20. Goldin, C. (1995), "The U-Shaped Female Labor Force Function in Economic Development and Economic History", Working Paper No. 4707, NBAER, Cambridge, Mass.

21. Hakim, C. (1996), “Key Issues in Women's Work: Female Heterogeneity and the Polarisation of Women's Employment", The Athlone Press Limited, London and Atlantic Highlands, NJ.

22. Hirway, I. (2002), "Employment and Unemployment Situation in 1990s: How Good Are NSS Data?", Economic and Political Weekly, Vol. 37, No. 21 (May 25-31, 2002), pp. 2027-2036.

23. Holmes, M. (2008), "Gender and Everyday Life the New Sociology", December, Rouletdge, https://books.google.co.in/books?isbn=1134098324, pp. 60.

24. ILO (2008), "Women, gender and the informal economy: An assessment of ILO research and suggested ways forward", Working Paper ILO, March, 2008.

25. Irwin, S. (2005), "Reshaping Social Life", Routledge, November 14, 2005, https://books.google.co.in/books?isbn=1134301383, pp. 70-71.

26. Jain, D. and Nirmala Banerjee. (1985) (eds). “Tyranny of the Household”, Delhi: Shakti Books.

27. Gujarati, D. N. (3rd Edition), "Basic Econometrics", Chapter 16.

28. Jain, D. and Nirmala Banerjee. (1985) (eds). "Tyranny of the Household", Delhi: Shakti Books. 


\section{Issue 2/2017}

29. Majumder, R. (2011), "Female Labour Supply in India: Proximate Determinants", MPRA Paper No.43250, September.

30. Mammen, K. and Christina Paxson. (2000), "Women's Work and Economic Development”, Journal of Economic Perspectives, Vol. 14, No. 4, pp. 141-164.

31. Masood, T. and Ahmad. Mohd. Izhar. (2009), "An Econometric analysis of Inter-State Variations in Women's Labour Force Participation in India", mpra.ub.unimuenchen.de.

32. McBride, A. et al (2014), "Intersectionality: are we taking enough notice in the field of work and employment relations?", Work Employment \& Society, September 8, 2014.

33. Mehrotra, S. et al. (2012), "Creating Employment in the Twelfth Five-Year Plan", Economic and Political Weekly, May 12, 2012, VOL. XLVII No. 19.

34. Neetha, N. (2013), "Inequalities Reinforced? Social Groups, Gender and Employment", Occasional Paper No.59, January 2013, Centre for Women's Development Studies.

35. Neff, D. et al. (2012), "The Puzzling Decline in Rural Women's Labor Force Participation in India: A Reexamination", GIGA Working Papers, No. 196, May 2012.

36. NSSO. 2011-12. Employment and Unemployment Situation in India, $68^{\text {th }}$ Round, Report No.554. Ministry of Statistics and Program Implementation, Government of India

37. Pastore, F. and Simona, Tenaglia. (2013), "Ora et non Labora? A Test of the Impact of Religion on Female Labor Supply", IZA DP No. 7356, April 2013.

38. Rangarajan, C. et al. (2014), "Developments in the Workforce between 2009-10 and 2011-12", Economic and Political Weekly June 7, 2014, Vol. XLIX, No. 23.

39. Roemer, J.E. (1982), "A General Theory of Exploitation and Class", Harvard University Press, https://books.google.pt/books?isbn=0674344405

40. Rubery, J., et al. (1999). "Women's Employment in Europe: Trends and prospects". London and New York: Routledge.

41. Sen, G. and Chiranjib Sen. (1985), "Women's Domestic Work and Economic Activity: Results from the National Sample Survey", Economic and Political Weekly, Vol. 20, No. 17.

42. Sethuraman, S.V. (1998), "Gender, informality and poverty: A global review", ILO Working Paper, (Geneva, ILO).

43. Shaw, A. (2013), "Employment Trends in India-An Overview of NSSO's 68th Round", Economic and Political Weekly October 19, 2013, Vol. XLVIII, No.42.

44. Srivastava, N. and Srivastava, R. (2010), "Women, Work and Employment Outcomes in Rural India", Economic and Political Weekly July 10, 2010, Vol. XLV No. 28.

45. Thomas, J.J. (2012), "India's labour market during the 2000s: Surveying the changes", Economic and Political Weekly, Vol. 47, No. 51, pp. 39-51.

46. World Development Report, (2012), "Gender Equality and Development" 
Issue $2 / 2017$

Table A1: Descriptive Statistics of the Independent Variables in section 3

\begin{tabular}{|c|c|c|}
\hline Independent Variables & Description & $\begin{array}{c}\text { Proportional } \\
\text { Representation }\end{array}$ \\
\hline Age & Categorical Variable & \\
\hline 15-29 & yes $=1$, no $=0$ Reference & $29.08 \%$ \\
\hline $30-44$ & yes $=1$, no $=0$ & $23.46 \%$ \\
\hline 45-59 & yes $=1$, no $=0$ & $15.43 \%$ \\
\hline Marital Status & Categorical Variable & \\
\hline Never Married & yes $=1$, no $=0$ Reference & $41.15 \%$ \\
\hline Currently Married & yes $=1$, no $=0$ & $53.35 \%$ \\
\hline Widowed & yes $=1$, no $=0$ & $5.15 \%$ \\
\hline Divorced Separated & yes $=1$, no $=0$ & $0.34 \%$ \\
\hline Education & Categorical Variable & \\
\hline Illiterate & yes $=1$, no $=0$, Reference & $23.70 \%$ \\
\hline Below Primary & yes $=1$, no $=0$ & $18.72 \%$ \\
\hline Primary and Middle & yes $=1$, no $=0$ & $32.66 \%$ \\
\hline Secondary and Higher secondary & yes $=1$, no $=0$ & $18.66 \%$ \\
\hline Graduate \& Above(diploma) & yes $=1$, no $=0$ & $5.62 \%$ \\
\hline Households with Children $($ age $<=5$ yrs $)$ & in numbers, Continuous Variable & $36.31 \%$ \\
\hline Households with Elderly(age > $=65 \mathrm{yrs})$ & in numbers, Continuous Variable & $23.20 \%$ \\
\hline Land-Ownership & Categorical Variable & \\
\hline Landless & yes $=1$, no $=0$, Reference & $0.22 \%$ \\
\hline Marginal Owners & yes $=1$, no $=0$ & $50.20 \%$ \\
\hline Small Owners & yes $=1$, no $=0$ & $31.68 \%$ \\
\hline Large Owners & yes $=1$, no $=0$ & $17.89 \%$ \\
\hline MPCE Quartile & Categorical Variable & \\
\hline Lowest Quartile & yes $=1$, no $=0$, Reference & $29.82 \%$ \\
\hline Second quartile & yes $=1$, no $=0$ & $28.58 \%$ \\
\hline Third quartile & yes $=1$, no $=0$ & $23.72 \%$ \\
\hline Fourth (highest) quartile & yes $=1$, no $=0$ & $15.88 \%$ \\
\hline Social Group & Categorical Variable & \\
\hline ST & yes $=1$, no $=0$, Reference & $16.74 \%$ \\
\hline SC & yes $=1$, no $=0$ & $16.58 \%$ \\
\hline
\end{tabular}


Issue $2 / 2017$

\begin{tabular}{|l|l|l|}
\hline OBC & yes $=1$, no $=0$ & $39.64 \%$ \\
\hline Others & yes $=1$, no=0 & $27.03 \%$ \\
\hline Religion & Categorical Variable & \\
\hline Hindu & yes $=1$, no=0, Reference & $74.68 \%$ \\
\hline Muslim & yes $=1$, no=0 & $12.87 \%$ \\
\hline Other-Religion & yes $=1$, no=0 & $12.45 \%$ \\
\hline Regions & Categorical Variable & \\
\hline East & yes $=1$, no=0, Reference & $10.66 \%$ \\
\hline West & yes $=1$, no=0 & $10.09 \%$ \\
\hline Central & yes=1, no=0 & $29.16 \%$ \\
\hline North & yes $=1$, no=0 & $16.56 \%$ \\
\hline South & yes $=1$, no=0 & $18.02 \%$ \\
\hline North-East & yes $=1$, no=0 & $15.50 \%$ \\
\hline
\end{tabular}

Author's calculation.

Source: NSSO $68^{\text {th }}$ Round Unit Level Data, 2011-12.

TableA2: Definition of variables used in Section 3

\begin{tabular}{|l|}
\hline Dependent Variable \\
\hline $\begin{array}{l}\text { The dependent variable in logistic regression analysis, participation in labour force, is a } \\
\text { dummy variable with value=1 if 'in the labour force' and value=0 if 'not in the labour } \\
\text { force' }\end{array}$ \\
\hline Independent Variables \\
\hline The independent variables of importance and interest are: \\
\hline i. Land ownership [coded as three dummies indicating marginal land owners $(0.001-$ \\
0.40 hectares), small land owners (0.40-2.00 hectares) and large landowners (>2.00 \\
hectares) with landless households being the reference category], \\
\hline ii. \begin{tabular}{l} 
Caste (coded as three dummies for Schedule Castes, OBCs, Others with Schedule \\
Tribe being the reference category) \\
iii. $\begin{array}{l}\text { Religion (coded as two dummies for Muslims and Other-Religions with Hindus as } \\
\text { the reference categories). }\end{array}$ \\
\hline iv. Several important control variables indicating demographic characteristics of the \\
individual (age, educational level, marital status) and the household (dependence \\
level, income level $\left.{ }^{24}\right)$, regional dummies have been incorporated in the model.
\end{tabular} \\
\hline
\end{tabular}

${ }^{24}$ As NSSO does not provide data on income of the households hence, following normal standard the data on monthly per capita consumption level of the household has been considered. 
TableA3: Definition of variables used in section 5

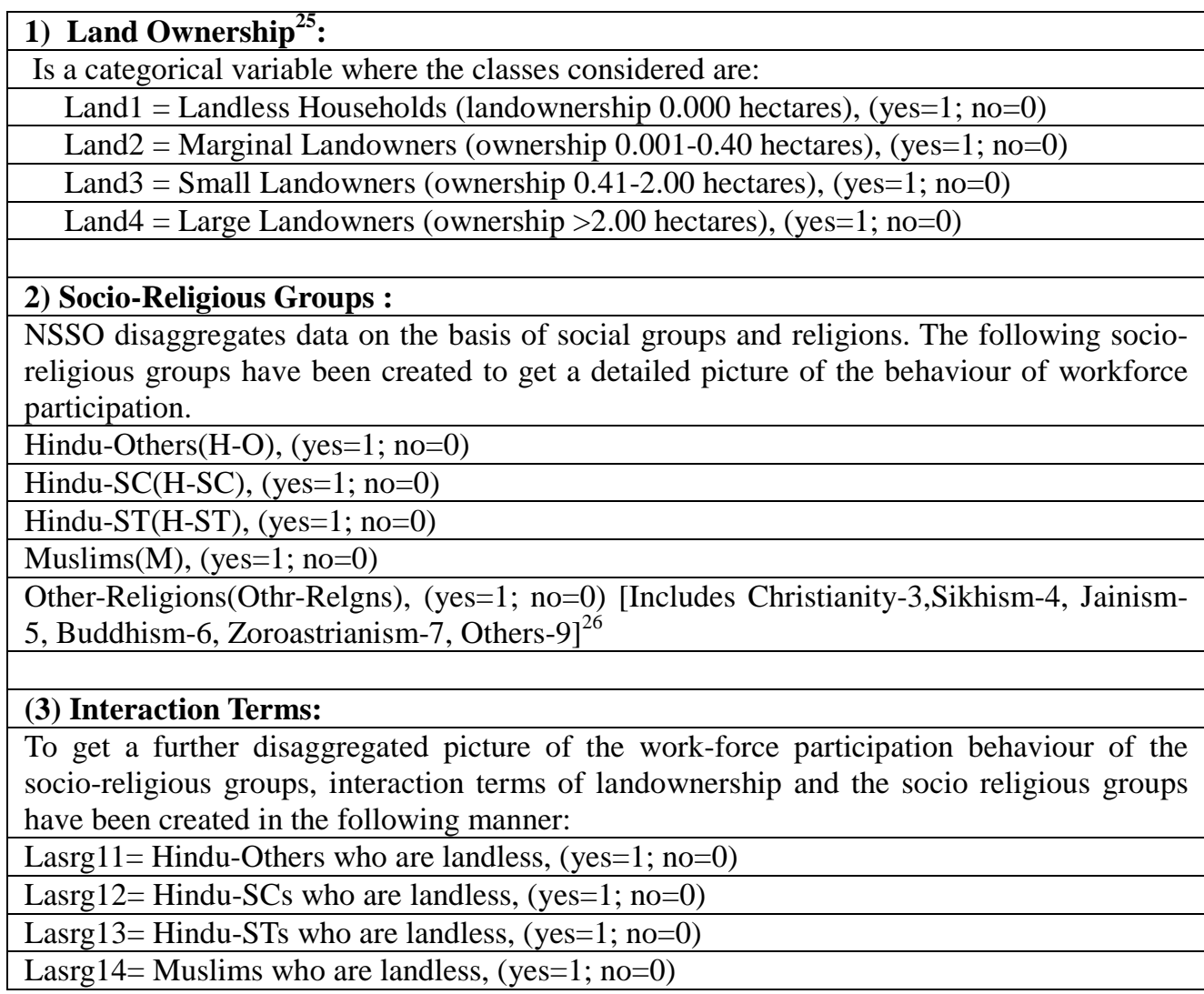

${ }^{25}$ The concept used in this paper of creating land-ownership categories has also been used by the following researchers in their papers:

(a) P.K. Bardhan (1979); where he has considered three main classes viz, Landless labourers, Small farmers (holdings $<2.5$ acres) and Large farmers (holding $>2.5$ acres)

(b) Supriya Garikipati (2006); where she has classified men and women labourers using 'labour class ranks' developed by Bardhan (1979) and DaCorta \& Venkateshwarlu (1999). It is based on Roemer's (1982) system and gives three labour classes: Pure Labourers, Labour Plus and Small Farmers.

${ }^{26}$ The steps involved in creating the socio-religious groups can be obtained from the author on request. 

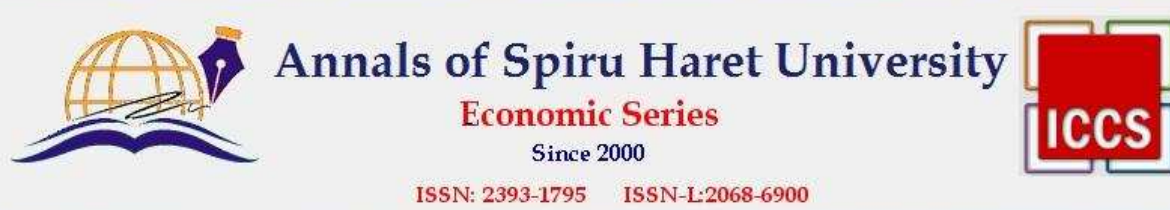

Issue $2 / 2017$

Lasrg 15= Other-Religions who are landless, (yes $=1 ; \mathrm{no}=0$ )

Lasrg21 = Hindu-Others who are marginal landowners, $($ yes $=1 ;$ no $=0$ )

Lasrg22 $=$ Hindu-SCs who are marginal landowners, $(y e s=1 ; n o=0)$

Lasrg23= Hindu-STs who are marginal landowners, (yes $=1 ;$ no $=0$ )

Lasrg24= Muslims who are marginal landowners, (yes $=1 ;$ no $=0$ )

Lasrg25= Other-Religions who are marginal landowners, (yes $=1 ;$ no $=0$ )

Lasrg31 $=$ Hindu-Others who are small landowners, (yes $=1 ;$ no $=0$ )

Lasrg32 $=$ Hindu-SCs who are small landowners, $($ yes $=1 ; n o=0)$

Lasrg33 = Hindu-STs who are small landowners, $($ yes $=1 ;$ no $=0)$

Lasrg34= Muslims who are small landowners, (yes $=1 ; \mathrm{no}=0$ )

Lasrg35= Other-religions who are small landowners, $($ yes $=1 ;$ no $=0$ )

Lasrg41 $=$ Hindu-Others who are large landowners, $(y e s=1 ;$ no $=0$ )

Lasrg $42=$ Hindu-SCs who are large landowners, $($ yes $=1 ; \mathrm{no}=0$ )

Lasrg43= Hindu-STs who are large landowners, $($ yes $=1 ; n o=0)$

Lasrg44= Muslims who are large landowners, (yes $=1 ; \mathrm{no}=0$ )

Lasrg $45=$ Other-Religions who are large landowners, (yes $=1 ;$ no $=0$ ) 